\title{
Jurnal Smart PAUD
}

p-ISSN 2599-0144, e-ISSN 2614-1248

Vol. 3, No.1, Januari 2020, Hal:1-9, Doi: http://dx.doi.org/10.36709/jspaud.v3i1.9337

Available Online at, http://ajs.uho.ac.id/index.php/smartpaud

\section{KOMERSIALISASI LEMBAGA PENDIDIKAN ANAK USIA DINI DI KOTA KENDARI}

\author{
La Hewi \\ ${ }^{1}$ Program Studi PIAUD Institut Agama Islam Negeri Kendari, Jl. Sultan Qaimuddin Nomor 17 \\ Baruga, Kendari 93116, Indonesia.
}

\begin{abstract}
Abstrak
Penelitian ini bertujuan untuk mendeskripsikan pembiayaan di lembaga pendidikan anak usia dini yang berada di kota Kendari masuk pada kategori komersialisasi atau tidak. Peneliti menggunakan pendekatan kualitatif untuk mendapatkan data yang komprehensif. Teknik pengumpulan data yang digunakan adalah wawancara, observasi dan studi dokumentasi. Adapun teknik analisis data dalam penelitian ini menggunakan interactive model dari Miles dan Huberman dengan langkah-langkah analisis data yaitu reduksi data, penyajian data, penarikan kesimpulan dan verifikasi. Teknik pemeriksaan keabsahan data yang digunakan adalah teknik credibility (derajat kepercayaan) yakni, triangulasi member check. Hasil penelitian menunjukkan bahwa pembiayaan pendidikan anak usia dini di kota Kendari berasal dari berbagai pihak mulai pemerintah, yayasan pendiri satuan PAUD dan orang tua peserta didik sebagai penerima layanan. Pembiayaan PAUD di kota Kendari bervariasi mulai dari pembiayaan jutaan sampai puluhan ribu bahkan ada pula yang membebaskan semua biaya pendidikan. Jadi pembiayaan PAUD di Kota Kendari belum masuk pada komersialisasi pendidikan.
\end{abstract}

Kata kunci: pembiayaan, komersialisasi, pendidikan anak usia dini

\section{COMMERCIALIZATION OF EARLY CHILDHOOD EDUCATION INSTITUTIONS IN KENDARI CITY}

\begin{abstract}
This study aims to describe the financing of early childhood education institutions in the city of kendari, in the category of commercialization or not. Researchers use a qualitative approach to get comprehensive data. Data collection techniques used were interviews, observation and documentation study. The data analysis technique in this study uses an interactive model from Miles and Huberman with data analysis steps namely data reduction, data presentation, drawing conclusions and verification. The data validity checking technique used is the credibility technique, namely member check triangulation. The results showed that the financing of early childhood education in the city of Kendari came from various parties from the government, founding foundations of PAUD units and parents of students as service recipients. PAUD financing in the city of Kendari varies from funding of millions to tens of thousands and some even free all education costs. So, PAUD financing in Kendari city has not yet entered into the commercialization of education.
\end{abstract}

Keywords: financing, commercialization, early childhood education

\section{PENDAHULUAN}

Fenomena pendirian lembaga-lembaga pendidikan anak usia dini (PAUD) di berbagai daerah akhir-akhir ini begitu menjamur. Begitu juga dengan fenomena orang tua yang memasukkan anaknya ke lembaga-lembaga PAUD sekarang ini telah banyak ditemukan. Hewi (2019) menyatakan bahwa untuk menyekolahkan anak ke satuan PAUD, orang tua (ibu) sampai menemani anak dalam kelas untuk belajar. Hal ini dapat dipahami sebagai bentuk kesadaran dari orang tua akan pentingnya anak mendapat stimulasi perkembangan yang sesuai dengan tahapan perkembangan usia anak. Keinginan orang tua untuk menyekolahkan anak mereka dilakukan dengan cara memasukan pada satuan PAUD sejak anak masih usia dini (Hewi, Saleh, \& Wahyuni, 2020). 
Data referensi Kementerian Pendidikan dan Kebudayaan tentang jumlah satuan pendidikan anak usia dini di Kota Kendari, diperoleh data bahwa jumlah satuan PAUD di Kota Kendari berjumlah 328 dari sepuluh kecamatan yang ada, mulai dari TK, KB, TPA dan SPS. Jumlah lembaga pendidikan anak usia dini (PAUD) untuk satuan Taman Kanak-Kanak (TK) di Kota Kendari berjumlah 201 lembaga, yaitu 5 lembaga negeri dan 196 lembaga swasta, sementara Kelompok Bermain (KB) berjumlah 110 lembaga sedangkan untuk jumlah lembaga Tempat Penitipan Anak (TPA) dan satuan PAUD sejenis (SPS) berjumlah 17 lembaga, yaitu 14 lembaga TPA (1 lembaga negeri dan 13 lembaga swasta) dan 3 lembaga SPS. Jumlah yang paling banyak jika dibandingkan dengan satuan PAUD di kabupaten/kota yang ada di Provinsi Sulawesi Tenggara.

Secara institusional pendidikan anak usia dini dapat diartikan jenjang pendidikan sebelum sekolah dasar yang memfokuskan layanannya pada pertumbuhan dan perkembangan anak. Ariyanti (2016) mengemukakan bahwa pendidikan anak usia dini meliputi semua hal baik upaya maupun tindakan yang dilakukan oleh guru (pendidik) dan orang tua dalam proses menstimulasi, membimbing, merawat dan mengasuh dalam hal pendidikan anak dengan menciptakan suasana dan lingkungan sehingga anak dapat mengeksplorasi pengalaman, mengetahui dan memahami pengalaman belajar yang diperoleh anak dari lingkungan, dengan cara mengamati, meniru, bereksperimen secara berulang-ulang dan melibatkan semua potensi dan kecerdasan anak.

Beberapa konsep pendidikan anak usia dini yang dikemukakan di atas dapat disintesiskan bahwa pendidikan anak usia dini merupakan layanan yang diberikan anak sejak lahir sampai usia 6 tahun agar semua potensi dapat berkembang melalui stimulasi semua aspek perkembangan. Menurut Hasyim (2015), pendidikan anak usia dini adalah jenjang pendidikan kelompok anak yang berada dalam proses pertumbuhan dan perkembangan yang berusia 0-6 tahun yang bersifat unik, dalam arti memiliki pola pertumbuhan dan perkembangan (koordinasi motorik halus dan kasar), inteligensia, sosial, emosional, bahasa dan komunikasi yang khusus sesuai dengan tingkat pertumbuhan dan perkembangan anak.

Suyadi dan Ulfah (2013) mengemukakan ada beberapa problem aktual pada pendidikan anak usia dini saat ini, yaitu antara lain: (1) biaya pendidikan anak usia dini relatif mahal sementara gaji guru PAUD relatif kecil, (2) guru PAUD disyaratkan bergelar S-1 PG-PAUD dalam realitanya guru PAUD masih di dominasi lulusan SMA sederajat. Pada dekade ini pemerintah mewacanakan wajib belajar 12 tahun, namun wacana berkembang hanya untuk SD/MI hingga SMA/MA. Pada saat yang sama, pemerintah juga membuat gerakan nasional berupa pendidikan karakter. Pembangunan karakter bangsa akan paling efektif jika dilakukan pada generasi yang masih berusia dini melalui PAUD.

Lembaga-lembaga PAUD baik Taman Kanak-Kanak/Raudhatul Athfal yang melayani anak usia 4 sampai 6 tahun maupun tempat penitipan anak yang melayani anak mulai dari rentang usia 3 bulan sampai usia tahunan. Memiliki sistem yang terdiri dari berbagai unsur yang saling berinteraksi dan saling mempengaruhi tidak hanya pada aspek pendidik, tenaga kependidikan dan peserta didik saja, tetapi juga dengan sarana dan prasarana serta waktu yang dibutuhkan dalam menjalankan program-program yang ditawarkan. Proses pembinaan di satuan PAUD membutuhkan sumber pembiayaan yang jelas dan berkesinambungan.

Pembiayaan dalam konteks pendidikan merupakan pembiayaan dalam rangka kegiatan pendanaan segala unsur kegiatan yang dilakukan, mulai dari pengadaan hingga biaya operasional baik personalia maupun nonpersonalia. Besar kecilnya pembiayaan pendidikan tergantung dari program maupun kegiatan yang dilakukan, sebab salah satu faktor yang mempengaruhi pelayanan dan mutu lulusan dari program pendidikan adalah biaya atau pendanaan. Pada umumnya, semakin besar biaya untuk penyelenggaraan pendidikan maka semakin baik pula layanan dan mutu lulusan dari program pendidikan tersebut.

Pembiayaan satuan PAUD terdiri dari beberapa sumber yaitu; (1) bantuan operasional Pendidikan dari Dinas Kabupaten/Kota, (2) pembayaran/ sumbangan wajib dari orang tua anak sebagai pengguna layanan pendidikan anak usia dini. Pembiayaan pendidikan anak usia dini yang berasal dari orang tua peserta didik sebagai pengguna layanan PAUD berbentuk biaya masuk sekolah (uang pangkal), pembayaran wajib setiap bulan (uang komite atau uang SPP), sumbangan mengikat kepada peserta didik dengan sistem pembayaran bulanan atau tahunan (infaq, sedekah atau uang kebersihan). 
Suharsaputra (2013) menyatakan bahwa kategori biaya pendidikan terdiri dari biaya langsung dan tidak langsung, biaya pribadi dan biaya sosial. Biaya langsung adalah biaya yang dikeluarkan untuk membiayai kebutuhan yang berkaitan langsung dengan hal-hal mendasar dengan pendidikan sehingga dapat terlaksana atau tidak, misalnya biaya untuk membayar tenaga pendidik, pembimbing, pegawai, pimpinan, penggadaan dan pemeliharaan perlengkapan marerial dan alat-alat pendidikan, pembelian tanah dan termasuk juga pembangunan gedung.

Anwar (2008) pendidikan yang kurang menghargai orang miskin akan terjebak pada arus komersialisasi, hampir semua kebijakan pengelolaan pendidikan tidak luput dari pertimbangan uang. Inilah sebab komersialisasi pendidikan yang didukung ekspansi kapitalisme global, yang merambah berbagai sendi kehidupan. Rustiawan (2015) menyatakan bahwa pendidikan yang semula sebagai proses humanisasi dan transformasi sosial mengalami distorsi dan menjadi ladang komersialisasi untuk menumpuk harta untuk kepentingan privasi. Beberapa kajian penelitian tentang komersialisasi pendidikan memfokuskan perhatian pada komersialisasi pendidikan di jenjang pendidikan tinggi misalnya Astri (2011) mengemukakan bahwa komersialisasi pendidikan tinggi di Indonesia itu ada. Begitu juga oleh Kahar (2007) menyatakan bahwa komersialisasi pendidikan terjadi karena pemerintah tidak dapat memberikan pendanaan yang memadai untuk pendidikan.

Kajian komersialisasi pendidikan untuk jenjang pendidikan dasar, secara khusus untuk pendidikan anak usia dini belum pernah ada. Tedjawati (2013) menyatakan bahwa pendanaan di pendidikan anak usia dini bersumber dari pemerintah belumlah memadai untuk biaya operasional lembaga PAUD sehingga pendanaan PAUD mengambil dari sumbangan dari orang tua peserta didik.

Komersialisasi merupakan istilah yang sangat populer di dunia ekonomi, karena dalam dunia ekonomi segala sesuatu diperjualbelikan. Hal ini juga sesuai jika komersialisasi ditinjau dari asal katanya, yaitu komersialisasi memiliki asal kata komersil yang berarti berhubungan dengan perdagangan. Menurut Buchtari dalam Kahar (2007) menyatakan bahwa di Indonesia untuk istilah komersialisasi pendidikan mengacu pada dua pengertian. Pertama, komersialisasi pendidikan mengacu pada lembaga pendidikan dengan program serta perlengkapan mahal. Pemungutan biaya yang tinggi diambil karena untuk memfasilitasi jasa pendidikan serta menyediakan sarana pendidikan yang bermutu. Kedua, komersialisasi pendidikan mengacu pada lembaga pendidikan yang hanya mementingkan uang seperti uang pendaftaran dan uang kuliah, namun mengabaikan kewajiban pendidikan.

Menurut Subijanto dalam Astri (2011) menyatakan bahwa ada lima indikator sebuah lembaga dikategorikan bersifat komersil, antara lain: (1) penyelenggaraan pendidikan menjadi sesuatu yang diperjualbelikan, penyelenggaraan pendidikan membutuhkan biaya mahal, (3) penyelenggaraan pendidikan tidak mengakomodir peserta didik kurang mampu secara ekonomi, (4) penyelenggaraan pendidikan tidak terdapat subsidi silang/dispensasi uang sekolah bagi siswa dari keluarga tidak mampu secara ekonomi, (5) penyelenggaraan pendidikan hanya untuk mencari keuntungan finansial. Masalah biaya pendidikan adalah merupakan masalah mendasar dalam penyelenggaraan pendidikan. Hal ini disebabkan oleh fakta bahwa penyelenggaraan pendidikan juga bersentuhan dengan masalah sarana, prasarana dan pembiayaan yang lain (insentif dan honorarium).

Pada kategori biaya yang harus dikeluarkan untuk membayar personil pimpinan dan tenaga pendidik bagi sekolah swasta adalah hal yang harus dianggarkan sesuai dengan kondisi keuangan sekolah (biaya ini habis begitu saja ketika sudah diterimakan kepada mereka). Biaya ini harus senantiasa tersedia dan atau dibayar atau dikeluarkan oleh pihak orang tua selama anaknya menjadi siswa di suatu sekolah.

Pada biaya penggadaan tanah, pembangunan gedung, bisa jadi orang tua siswa tidak setiap masuk sekolah harus membayar uang gedung (pembangunan) terutama untuk sekolah yang sudah mempunyai gedung yang representatif (jika harus membayar, barangkali adalah uang untuk pemeliharaan gedung) (Maisah, 2013). Sementara itu biaya yang tidak langsung adalah biaya yang harus dikeluarkan oleh sekolah dan atau dibayarkan oleh orang tua siswa (secara tidak langsung). Oleh karena munculnya sebagai implikasi dari penggunaan suatu fasilitas sarana dan prasarana, misalnya pajak listrik, air, kendaraan bermotor, bangunan dan fasilitas-fasilitas lain yang ditetapkan oleh pemerintah. Jenis biaya ini adalah biaya yang jelas secara langsung seakan-akan tidak ada kaitannya dengan biaya proses pendidikan, 
namun secara administratif kelembagaan harus dikeluarkan. Pengeluaran jenis biaya tidak langsung ini adalah kewajiban kelembagaan dan tidak ada sangkut pautnya dengan jumlah dan keadaan siswa didiknya. Ini artinya sekolah yang mempunyai siswa banyak ataukah sedikit, biaya-biaya diatas tetap harus dibayarkan. (Maisah, 2013)

Biaya pribadi adalah biaya pendidikan yang harus dikeluarkan oleh setiap orang tua siswa/wali yang ada kaitannya kelancaran belajar atau studi anaknya, sehingga biaya ini harus ditanggung sendiri dimana jenis, ragam, kualitas dan jumlahnya sangat tergantung pada pribadi dan kebutuhan anak-anak masingmasing. Contoh biaya pribadi ini ialah pemilihan buku, alat tulis, ongkos transportasi siswa untuk ke sekolah dan kepulangannya, serta biaya makan dan minum. Kebutuhan-kebutuhan tersebut, pihak sekolah tidak menarik biaya dan tidak mengalokasi anggarannya (Suharsaputra, 2013)

Biaya sosial adalah jenis biaya yang dikeluarkan dan atau dibutuhkan oleh pihak siswa yang ada kaitannya dengan kelancaran siswa dalam menempuh studi. Biaya ini dibayarkan secara tidak langsung oleh orang tua siswa melalui pihak sekolah dengan membayar pajak kepada pemerintah, kemudian pemerintah memberi kompensasi hibah kepada masyarakat melalui sekolah, misalnya berupa hibah sumbangan dan sejenisnya.

\section{METODE}

Metode penelitian yang digunakan dalam penelitian ini adalah kualitatif. Penggunaan pendekatan kualitatif digunakan untuk memperoleh pemahaman mendalam tentang pembiayaan lembaga pendidikan anak usia dini di kota kendari. Selanjutnya, dideskripsikan hasil temuan dan pemahaman dalam bentuk ungkapan bahasa yang tepat dan sistematis berdasarkan fakta-fakta yang ada dalam penelitian.

Pendekatan kualitatif memiliki beberapa strategi yang spesifik, yang dalam penelitian ini menggunakan studi fenomenologis. Creswell menyatakan bahwa studi fenomenologis memberikan pemaknaan umum dari sejumlah individu terhadap berbagai pengalaman hidup terkait konsep dan fenomena (Creswell, 2015). Penelitian ini memahami permasalahan secara mendalam adalah pembiayaan pendidikan di lembaga pendidikan anak usia dini di Kota Kendari. Studi fenomenologis ini membantu peneliti menemukan esensi dari penentuan biaya yang dilakukan oleh lembaga-lembaga PAUD yang ada di Kota Kendari.

Penelitian ini dilakukan di Kota Kendari, dengan waktu pelaksanaan dari bulai Mei sampai Oktober 2018. Adapun subjek penelitian yaitu lembaga-lembaga PAUD yang ada di Kota Kendari sebanyak sepuluh lembaga PAUD yang ditentukan secara purposive sampling sehingga lembaga PAUD yang dipilih peneliti berdasarkan tujuan penelitian adalah TK Islam Kemaraya Kendari, TK Kemala Bhayangkari 26, TK Bina Bangsa Baruga, TK Satria Darul Dakwah Al-Irsyad, TK Dewi Srikandi, TK Aulia Perip, Raudhatul Atfal Riyadhus Shalihin, PAUD Budi Lestari, TK Islam Nurhaq dan TK Kuncup Pertiwi. Guru atau Kepala PAUD yang menjadi sumber informasi peneliti termaksud Kepala Dinas Pendidikan dan Kabid PAUDNI serta Pengawas Lembaga PAUD agar data yang diperoleh akurat.

Teknik pengumpulan data yang peneliti gunakan adalah wawancara, observasi dan studi dokumentasi. Adapun teknik analisis data dalam penelitian ini menggunakan interactive model dari Miles, Huberman, \& Saldana (2014) dengan langkah-langkah analisis data yaitu reduksi data, penyajian data, penarikan kesimpulan dan verifikasi. Teknik pemeriksaan keabsahan data yang digunakan adalah teknik credibility (derajat kepercayaan) yakni, triangulasi member check.

\section{HASIL DAN PEMBAHASAN}

Pembiayaan pendidikan anak usia dini di kota Kendari berasal dari berbagai pihak mulai Pemerintah/ Dinas Pendidikan Kepemudaan dan Olahraga Kota Kendari, Yayasan pendiri satuan/lembaga pendidikan anak usia dini dan orang tua peserta didik sebagai penerima layanan.

Pemerintah dalam hal ini Dinas Pendidikan Kepemudaan dan Olahraga Kota Kendari memberi bantuan pendanaan melalui pemberian bantuan operasional kepada semua lembaga/satuan pendidikan anak usia dini seluruh Kota Kendari baik lembaga negeri maupun swasta. Dinas Pendidikan Kepemudaan dan Olahraga Kota Kendari memberikan bantuan pendanaan kepada seluruh satuan PAUD yang telah memiliki izin operasional, nomor pokok sekolah nasional dan selalu mengupdate data siswa setiap tahun ajaran baru di data Dapodik. Sarita menyatakan bahwa Pemerintah Kota Kendari memberikan dana 
bantuan operasional kepada suluruh satuan PAUD dengan tidak melihat apakah sekolah yang bersangkutan itu negeri atau swasta. Seluruh satuan yang memenuhi syarat semua diberikan dana BOP (Sartini Sarita, kepala dinas Pendidikan Kepemudaan dan Olahraga Kota Kendari, tanggal 21 september 2018).

Besaran dana bantuan operasional pendidikan yang diberikan kepada satuan/lembaga pendidikan penerima adalah $\mathrm{Rp}$. 600.000 ,- (enam ratus ribu rupiah) per satu peserta didik. Dengan mekanisme pembayaran langsung diberikan kepada satuan/lembaga pendidikan anak usia dini penerima bantuan operasional pendidikan dengan cara langsung ditransfer ke dalam rekening masing-masing satuan/lembaga PAUD. Bantuan operasional pendidikan PAUD menjadi tanggung jawab sepenuhnya masing-masing satuan/ lembaga pendidikan anak usia dini penerima BOP PAUD yang dalam penggunaannya satuan atau lembaga pendidikan anak usia dini berpedoman pada Peraturan Menteri Pendidikan dan Kebudayaan Republik Indonesia nomor 2 tahun 2018 tentang petunjuk teknis penggunaan dana alokasi khusus nonfisik bantuan operasional penyelenggaraan pendidikan anak usia dini tahun 2018. Monitoring dan evaluasi penggunaan BOP PAUD dilakukan oleh Tim dari Direktorat PAUD, Inspektorat dan BPK serta Dinas pendidikan kepemudaan dan olahraga dalam hal ini di bawah kontrol kepala bidang pendidikan anak usia dini dan pendidikan nonformal kota Kendari.

Bantuan operasional pendidikan PAUD menjadi tanggung jawab sepenuhnya masingmasing satuan PAUD penerima BOP PAUD. Namun dalam penggunaannya satuan PAUD tidak bisa memakai dana tersebut berdasarkan kehendak pribadi kepala satuan pendidikan anak usia dini tetapi harus memperhatikan beberapa hal yang telah ditentukan dalam Peraturan Menteri Pendidikan dan Kebudayaan Republik Indonesia nomor 2 tahun 2018 tentang petunjuk teknis penggunaan dana alokasi khusus nonfisik bantuan operasional penyelenggaraan pendidikan anak usia dini tahun 2018. Ada tiga komponen penggunaan BOP PAUD antara lain pertama kegiatan pembelajaran dan bermain dengan presentase sebesar $50 \%$, kedua kegiatan pendukung dengan presentase sebesar $35 \%$, dan ketiga kegiatan lainnya dengan presentase sebesar $15 \%$.

Penjelasan secara detail tentang komponen penggunaan bantuan operasional pendidikan untuk seluruh lembaga pendidikan anak usia dini sesuai dengan Peraturan Menteri Pendidikan dan Kebudayaan Republik Indonesia nomor 2 tahun 2018 tentang petunjuk teknis penggunaan dana alokasi khusus nonfisik bantuan operasional penyelenggaraan pendidikan anak usia dini yaitu pertama komponen kegiatan pembelajaran dan bermain terdiri dari bahan bermain dan bahan belajar PAUD yang dibutuhkan sesuai dengan kegiatan dan tematik; peralatan pembelajaran seperti kertas, krayon, spidol, pensil, bahan pakai habis dan bahan pembelajaran sejenis lainnya; dan kegiatan pertemuan dengan orang tua/wali murid (kegiatan parenting). Keseluruhan pendanaan untuk semua kegiatan pada komponen kegiatan pembelajaran dan bermain adalah 50\% (lima puluh persen) dari seluruh dana BOP yang diterima. Kedua komponen kegiatan pendukung terdiri dari penyediaan buku administrasi; pembelian alat-alat Deteksi Dini Tumbuh Kembang (DDTK), pembelian obat-obatan ringan, dan isi kotak Pertolongan Pertama Pada Kecelakaan (P3K); biaya pertemuan guru di kegiatan Gugus PAUD, menghadiri kegiatan peningkatan kapasitas pendidik, dan transportasi petugas kesehatan kunjung; menambah transportasi pendidik; penyediaan makanan sehat. Keseluruhan pendanaan untuk semua kegiatan pada komponen kegiatan pendukung adalah 35\% (tiga puluh lima persen) dari seluruh dana BOP yang diterima. Dan terakhir komponen kegiatan lainnya terdiri dari Perawatan sarana dan prasarana termasuk perbaikan dan pengecatan ringan; Dukungan penyediaan alat-alat publikasi PAUD (leaflet, booklet, poster, papan nama); Langganan listrik, telepon/internet, air. Keseluruhan pendanaan untuk semua kegiatan pada komponen kegiatan lainnya adalah $15 \%$ (lima belas persen) dari seluruh dana BOP yang diterima.

Adapun larangan penggunan BOP yang diterima oleh seluruh satuan PAUD adalah sebagai berikut:

- Disimpan dengan maksud dibungakan

- Dipinjamkan kepada pihak lain

- Membiayai kegiatan yang tidak menjadi prioritas satuan PAUD

- Membayar iuran kegiatan yang diselenggarakan oleh unit pelaksana teknis daerah kecamatan/ kabupaten/ kota/ provinsi/ pusat, atau pihak lain kecuali untuk menanggung biaya peserta 
didik/pendidik yang ikut serta dalam kegiatan tersebut

- Membeli pakaian/seragam/sepatu bagi pendidik/peserta didik untuk kepentingan pribadi (bukan inventaris PAUD), kecuali bagi peserta didik miskin

- Digunakan untuk rehabilitasi

- Membangun gedung/ruangan baru

- Pembelian alat permainan edukatif dalam ruang dan luar ruangan

- Pembelian barang fisik seperti laptop, computer, printer, tape recorder, LCD proyektor dan sebagainya.

- Pembelian mebel

- Membiayai kegiatan yang telah dibiayai dari sumber dana pemerintah pusat atau pemerintah daerah secara penuh/wajar

- Membiayai kegiatan penunjang yang tidak ada kaitannya dengan operasional satuan PAUD misalnya membiayai iuran dalam rangka perayaan hari besar nasional upacara keagamaan/acara keagamaan, iuran organisasi dan lain sebagainya

- Membiayai kegiatan dalam rangka mengikuti pelatihan/ sosialisasi/ pendampingan terkait program dana alokasi khusus nonfisik BOP PAUD/perpajakan program DAK nonfisik BOP PAUD yang diselenggarakan satuan pendidikan nonformal di luar satuan kerja perangkat daerah pendidikan provinsi/kabupaten/kota dan kementerian pendidikan dan kebudayaan

- Membeli buku, alat dan bahan pembelajaran/bahan main yang mengandung kekerasan, paham kebencian, pornografi dan suku, agama dan ras

- Membiayai keperluan apapun di luar Rencana kegiatan dan anggaran satuan yang telah diajukan oleh satuan PAUD

Penggunaan bantuan operasional pendidikan yang mempunyai ketentuan rigid membuat lembaga PAUD meminta pembayaran pada penerima layanan PAUD yaitu orang tua peserta didik, hal ini untuk membiayai pembiayaan operasional lembaga yang tidak dapat dibiayai dengan menggunakan dana bantuan operasional pendidikan. Penentuan besaran biaya antara satu lembaga PAUD dengan lembaga PAUD yang lain bervariasi. Hal ini terjadi karena Dinas Pendidikan Kepemudaan dan Olahraga Kota Kendari tidak menentukan besaran biaya yang diambil oleh lembaga PAUD dari orang tua peserta didik.
Naniyatin menyatakan bahwa dinas pendidikan kepemudaan dan olahraga kota Kendari tidak pernah mengeluarkan surat edaran atau himbauan maupun semacamnya untuk menentukan atau melarang lembaga/satuan PAUD untuk memungut SPP dari peserta didik. Seluruh keputusan diserahkan kepada masingmasing lembaga PAUD untuk kepentingan pendanaan kegiatan operasional lembaga PAUD yang bersangkutan (Naniyatin, kepala bidang pendidikan anak usia dini dan pendidikan nonformal Kota Kendari, tanggal 24 september 2018).

Nismah menyatakan bahwa pembiayaan pendidikan anak usia dini di kota Kendari ada yang dipungut dari orang tua peserta didik sebagai SPP yang harus dibayarkan ke lembaga setiap bulan. Untuk nominal SPP setiap lembaga tergantung keputusan lembaga yang bersangkutan tetapi akan tinggi biaya tersebut karena satuan/lembaga PAUD membuka layanan sehari penuh (Full day) (Nismah, pengawas lembaga pendidikan anak usia dini dan pendidikan nonformal Kota Kendari, tanggal 27 september 2018)

Banyaknya lembaga PAUD di Kota kendari, berjumlah 287 yang secara keseluruhan adalah lembaga PAUD yang masih berbadan hukum yayasan atau swasta, dalam hal ini di bawah penyelenggaraan dan kontrol yayasan pendiri satuan pendidikan anak usia dini. Dari keseluruhan jumlah yang ada hanya ada 6 lembaga/satuan PAUD berstatus negeri, terdiri dari 5 lembaga/satuan Taman Kanak-Kanak (TK) dan 1 satuan Tempat Penitipan Anak (TPA). Pembayaran SPP dari peserta didik sepenuhnya di kelola oleh yayasan atau lembaga/satuan PAUD dan laporan pertanggungjawabannya tidak berhubungan dengan Dinas Pendidikan Kepemudaan dan Olahraga Kota Kendari tetapi kepada masyarakat pengguna jasa lembaga/satuan PAUD. Berikut ini daftar pembiayaan PAUD di lembaga/satuan pendidikan anak usia dini yang ada di Kota Kendari seperti pada Tabel berikut.

Tabel 1. Daftar Pembiayaan di Lembaga/satuan PAUD yang ada di Kota Kendari

\begin{tabular}{ccl}
\hline $\begin{array}{c}\text { Nama satuan } \\
\text { PAUD }\end{array}$ & $\begin{array}{c}\text { Aspek } \\
\text { Pembiayaan }\end{array}$ & \multicolumn{1}{c}{ Jumlah $(\mathbf{R p )}$} \\
TK IKK & Masuk & $2.500 .000,-$ \\
& Bulanan & $250.000,-$ \\
TK KB 26 & Masuk & $1.200 .000,-$ \\
& Bulanan & $95.000,-$ \\
\hline
\end{tabular}




\begin{tabular}{ccl}
\hline $\begin{array}{c}\text { Nama satuan } \\
\text { PAUD }\end{array}$ & $\begin{array}{c}\text { Aspek } \\
\text { Pembiayaan }\end{array}$ & Jumlah (Rp) \\
TK BBB & Masuk & $0,-$ \\
& Bulanan & 100.000 \\
TK SDD & Masuk & $350.000,-$ \\
& Bulanan & $70.000,-$ \\
TK DS & Masuk & $600.000,-$ \\
& Bulanan & $60.000,-$ \\
TK AP & Masuk & $950.000,-$ \\
& Bulanan & $7 \mathrm{~K} .000,-$ \\
RA RS & Masuk & $800.000,-$ \\
& Bulanan & $100.000,-$ \\
PAUD BL & Masuk & $50.000,-$ \\
& Bulanan & $50.000,-$ \\
TK IN & Masuk & $75.000,-$ \\
& Bulanan & $0,-$ \\
TK KP & Masuk & $1.000 .000,-$ \\
& Bulanan & $130.000,-$ \\
\hline
\end{tabular}

Beberapa lembaga/satuan pendidikan anak usia dini berdasarkan tabel di atas menetapkan pembiayaan yang beragam untuk selanjutnya dibebankan kepada orang tua peserta didik, yaitu pertama TK IKK menetapkan biaya awal masuk sekolah adalah sebesar Rp. 1.000.000,- (satu juta rupiah), sementara Infaq dan sedekah (pembayaran wajib setiap tahun) sebesar $\mathrm{Rp}$. 1.500.000,- (satu juta lima ratus ribu rupiah), sedangkan untuk uang SPP setiap bulan sebesar Rp. 250.000,- (dua ratus lima puluh ribu rupiah). Kedua TK KB 26 menetapkan pembayaran awal masuk sekolah adalah sebesar Rp. 1.200.000,(satu juta dua ratus ribu rupiah), sementara untuk pembayaran wajib setiap bulan di tetapkan sebesar Rp. 95.000,- (sembilan puluh lima ribu rupiah). Ketiga TK BBB menetapkan pembayaran awal masuk sekolah itu gratis, sedangkan pembayaran wajib setiap bulan (SPP) sebesar Rp. 100.000,- (seratus ribu rupiah) tetapi jika peserta didik yang bersangkutan berasal dari keluarga pra sejahtera maka biaya pembayaran wajib bulanan adalah setengah dari pembayaran yang ditetapkan oleh lembaga yaitu sebesar Rp. 50.000,- (lima puluh ribu rupiah). Keempat TK SDD menetapkan pembayaran uang pangkal yang dibayarkan awal masuk sekolah adalah sebesar Rp. 350.000,- (tiga ratus lima puluh ribu rupiah). Sementara untuk pembayaran SPP adalah sebesar Rp. 60.000,- (enam puluh ribu rupiah), sedangkan untuk pembayaran (uang) kebersihan sekolah adalah sebesar Rp. 10.000,(sepuluh ribu rupiah). Kelima TK DS pembayaran awal masuk sekolah atau biaya administrasi sebesar Rp. 600.000,- (enam ratus ribu rupiah). Sementara untuk pembayaran wajib setiap bulan atau uang komite ditetapkan sebesarKRp. 50.000,- (lima puluh ribu rupiah). Keenam TK AP menetapkan pembayaran awal masuk sekolah sebesar Rp. 950.000,- (sembilan ratus lima puluh ribu rupiah). Sementara untuk pembayaran wajib setiap bulan atau uang SPP ditetapkan sebesar Rp. 75.000,- (tujuh puluh lima ribu rupiah). Ketujuh RA RS menetapkan pembayaran awal masuk sekolah adalah sebesar Rp. 800.000,- (delapan ratus ribu rupiah). Sementara untuk pembayaran SPP bulanan adalah sebesar Rp. 30.000,- (tiga puluh ribu rupiah), sedangkan untuk pembayaran (uang) infak adalah sebesar Rp. 70.000,- (tujuh puluh ribu rupiah). Kedelapan PAUD BL menetapkan pembayaran awal masuk sekolah adalah sebesar Rp. 50.000,- (lima puluh ribu rupiah). Sementara untuk pembayaran SPP bulanan adalah sebesar Rp. 50.000,- (lima puluh ribu rupiah). Kesembilan TK IN menetapkan pembayaran pertama masuk sekolah sebesar Rp. 75.000,- (tujuh puluh lima ribu rupiah) sedangkan untuk pembayaran iuran bulanan digratiskan. Layanan full day sebesar $\mathrm{Rp}$. 400.000,- (empat ratus ribu rupiah) dibayar setiap bulan. Kesepuluh TK KP menetapkan pembayaran awal masuk sekolah adalah sebesar Rp. 1.000.000,- (satu juta rupiah), sedangkan untuk pembayaran SPP setiap bulanan adalah sebesar Rp. 130.000,- (seratus tiga puluh ribu rupiah).

Pembiayaan pendidikan anak usia dini yang bervariasi dari semua lembaga/satuan pendidikan anak usia dini, pada dasarnya digunakan untuk layanan yang akan diberikan oleh satuan/lembaga pendidikan anak usia dini sebagai penyedia layanan. Pembiayaan yang tinggi juga diikuti dengan pemberian fasilitas yang baik dan bermutu. TK IK menetapkan pembayaran awal sebesar Rp. 1.000.000,- (satu juta rupiah), ini akan langsung kembali pada peserta didik dalam bentuk layanan dan seragam dan peralatan sekolah. Begitu pula dengan uang infaq tahunan yang harus bayar oleh peserta didik sebesar Rp. 1.500.000,- (satu juta lima ratus tibu rupiah), kembali kepada peserta didik dalam bentuk sarana gedung yang memadai dan representatif untuk pengembangan dan stimulasi seluruh aspek perkembangan anak usia dini. Hal yang sama juga untuk seluruh layanan/lembaga pendidikan anak usia dini yang ada di kota Kendari. Bahwa pembiayaan yang tinggi selalu diikuti dengan pemberian layanan dan fasilitas yang memadai seperti TK KP menetapkan 
pembayaran awal masuk sekolah adalah sebesar Rp. 1.000.000,- (satu juta rupiah), yang kembali kepada peserta didik dalam bentuk layanan dan fasilitas seragam yang lengkap dan peralatan sekolah sedangkan untuk pembayaran SPP setiap bulanan adalah sebesar Rp. 130.000,(seratus tiga puluh ribu rupiah), kembali kepada peserta didik dalam bentuk layanan sarana alat permainan edukatif yang representatif untuk stimulasi perkembangan anak usia dini dengan pembelajaran sentra yang diberikan lembaga/satuan pendidikan anak usia dini.

Sementara untuk pembiayaan pendidikan anak usia dini yang berasal dari yayasan biasanya berbentuk bantuan dana untuk pengadaan gedung atau sumbangan yang tidak mengikat dari pengurus yayasan lembaga/satuan pendidikan anak usia dini. Berbeda dengan pembiayaan pendidikan anak usia dini yang berasal dari orang tua peserta didik sebagai pengguna layanan PAUD berbentuk biaya masuk sekolah (uang pangkal), pembayaran wajib setiap bulan (uang komite atau uang SPP), sumbangan mengikat kepada peserta didik dengan sistem pembayaran bulanan atau tahunan (infaq, sedekah atau uang kebersihan), keseluruhan biaya pendidikan ini menjadi tanggung jawab orang tua peserta didik pengguna layanan pendidikan anak usia dini.

Pembiayaan pendidikan anak usia dini di

Kota Kendari jika dipakai istilah komersialisasi pendidikan yang dikemukan oleh Asmirawanti, Sulfasyah, \& Arifin (2016) menyatakan bahwa bentuk komersialisasi pendidikan yang terjadi ada tiga yaitu: biaya pendidikan mahal, banyaknya pungutan-pungutan lembaga pendidikan, perdagangan di dunia pendidikan. Jika dikaitkan dengan hasil penelitian ini, maka dapat dikatakan bahwa pembiayaan pendidikan anak usia dini di Kota Kendari yang mengarah kepada pengertian komersialisasi belumlah sepenuhnya tepat. Hasil penelitian ini juga didukung oleh pernyataan Rustiawan (2015) bahwa komersialisasi pendidikan dapat terjadi karena berbagai faktor, diantaranya: akibat dari idiologi kapitalisme liberalisme, mentalitas sumber daya manusia, pemberian otonomi pembiayaan sebahagian atau seluruhnya kepada lembaga pendidikan sehingga memberikan peluang yang lebar untuk menarik pembiayaan pendidikan guna kepentingan mendapat profit semata-mata.

Begitu juga dengan lima indikator sebuah lembaga pendidikan dikategorikan bersifat komersil menurut Subijanto dalam Astri (2011) yaitu: pertama, penyelenggaraan pendidikan menjadi sesuatu yang diperjualbelikan. Kedua, penyelenggaraan pendidikan membutuhkan biaya mahal. Ketiga, penyelenggaraan pendidikan tidak mengakomodir peserta didik kurang mampu secara ekonomi. Keempat, penyelenggaraan pendidikan tidak terdapat subsidi silang/dispensasi uang sekolah bagi siswa dari keluarga tidak mampu secara ekonomi. Kelima, penyelenggaraan pendidikan hanya untuk mencari keuntungan finansial. Jika dipakai untuk memberikan vonis pada pembiayaan pendidikan anak usia dini di kota Kendari apakah bersifat komersil atau tidak maka dapat dikemukakan jawaban bahwa pembiayaan pendidikan anak usia dini di Kota Kendari belumlah dapat dikatakan komersil

\section{SIMPULAN DAN SARAN}

\section{Simpulan}

Berdasarkan hasil penelitian yang telah dipaparkan di atas, maka dapat disimpulkan bahwa pembiayaan pendidikan anak usia dini di Kota Kendari sangat bervariasi dari nominal jutaan sampai tidak dipungut biaya atau gratisan. Pembiayaan yang tinggi juga diikuti dengan pemberian fasilitas yang baik dan bermutu. Pembiayaan yang tinggi dari satuan PAUD akan langsung kembali pada peserta didik dalam bentuk layanan dan seragam dan peralatan sekolah serta sarana gedung yang memadai dan representatif untuk pengembangan dan stimulasi seluruh aspek perkembangan anak usia dini. Pembiayaan terhadap layanan satuan pendidikan anak usia dini di Kota Kendari apabila menggunakan istilah komersialisasi pendidikan belumlah tepat untuk dikatakan komersil.

\section{Saran}

Beberapa saran terkait hasil penelitian in diantaranya: (1) bagi sekolah yaitu penentuan biaya yang harus dikeluarkan oleh orang tua peserta didik sebagai pengguna layanan sebaiknya dengan melihat kemampuan finansial masyarakat di sekitar lembaga/satuan pendidikan anak usia dini yang bersangkutan sehingga tidak memberatkan serta perlu adanya subsidi silang antara peserta didik yang mampu dan kurang mampu secara finansial, (2) Pemerinath Kota Kendari yaitu perlu mengeluarkan surat edaran kepada seluruh satuan/lembaga pendidikan anak usia dini yang berada di bawah pengawasannya tentang standar besaran pembiayaan layanan mulai dari biaya 
masuk sekolah, biaya wajib setiap bulan maupun biaya-biaya lainnya, (3) orang tua yaitu perlu selektif untuk memilih satuan/lembaga pendidikan anak usia dini yang akan dijadikan pemberi layanan pendidikan kepada anakanaknya, baik dari segi keterjangkauan biaya maupun layanan dari lembaga/satuan pendidikan anak usia dini yang bersangkutan.

\section{DAFTAR PUSTAKA}

Anwar, W. (2008). Komersialisasi dan Tanggung jawab Pendidikan: Sekelumit Pembicaraan. Insania: Jurnal Pemikiran Alternatif Kependidikan, 13(3), 394413. https://doi.org/10.24090/insania.v13i3.3 05 .

Arianti, T. (2016). Pentingnya Pendidikan Anak Usia Dini Bagi Tumbuh Kembang Anak, Dinamika (Jurnal Pendidikan Dasar, $\quad$ VIII(1), 50-58. http://dx.doi.org/10.30595/dinamika.v8i 1.943

Asmirawanti, Sulfasyah, \& Arifin, J. (2016). Komersialisasi Pendidikan. Equilibrium: Jurnal Pendidikan, 4 (2), 174-183. https://doi.org/10.26618/equilibrium.v4i 2.499

Astri, H. (2011). Dampak Sosial Komersialisasi Pendidikan Tinggi di Indonesia. Kajian: Menjembatani Teori dan Persoalan Masyarakat dalam Perumusan Kebijakan, 16(3), 599-626. https://doi.org/10.22212/kajian.v16i3.53 7

Creswell, J. W. (2015). Research Design Pendekatan Kualitatif, Kuantitatif, dan Mixed . Yogyakarta: Pustaka Pelajar.

Hasyim, S. L. (2015). Pendidikan Anak Usia Dini Dalam Perspektif Islam. Jurnal Lentera: Kajian Keagamaan, Keilmuan dan Teknologi , 1(2), 217-226.

Hewi, L, Saleh, M., \& Wahyuni, R. (2020). Kelekatan (Attachment) Anak Usia Dini di Suku Laut Kabupaten Wakatobi. Jurnal Obsesi, 4(1), 406-415. https://doi.org/10.31004/obsesi.v4i1.346

Hewi, L. (2019). Pengasuhan Anak Usia Dini Di Suku Laut Kabupaten Wakatobi. Jurnal Golden Age, 3(2), 73-83.
Kahar, I. A. 2007. Komersialisasi Pendidikan di Indonesia: Suatu Tinjauan dari Aspek Politik, Ekonomi, Sosial dan Budaya. Ragam , 23(11), 49-53.

Maisah. (2013). Manajemen Pendidikan. Ciputat: Referensi (Gaung Perasada Press Group).

Miles, M. B., Huberman, A. M., \& Saldana, J. (2014). Qualitative Data Analysis, A Methods Sourcebook, Edition 3. USA: Sage Publications.

Rustiawan, H. (2015). Komersialisasi Pendidikan (Analisis Pembiayaan Pendidikan). Tazkiya (Jurnal Keislaman, Kemasyarakatan dan Kebudayaan), 16 (1), 44-63.

Suharsaputra, U. (2013). Administrasi Pendidikan. Bandung: Redika Aditama.

Suyadi, \& Ulfa, M.. (2013). Konsep Dasar PAUD. Bandung: Remaja Rosdakarya.

Tedjawati, J. M. (2013). Pendanaan Pendidikan Anak Usia Dini. Jurnal Pendidikan dan Kebudayaan, 19(3), 346-363. http://dx.doi.org/10.24832\%2Fjpnk.v19i 3.294 . 